\title{
B7-H3 silencing inhibits tumor progression of mantle cell lymphoma and enhances chemosensitivity
}

\author{
WEI ZHANG, YANFANG WANG, JING WANG, FEI DONG, MINGXIA ZHU, WENLI WAN, \\ HAISHEN LI, FEIFEI WU, XINXING YAN and XIAOYAN KE
}

Department of Hematology and Lymphoma Research Center, Peking University Third Hospital, Beijing 100191, P.R. China

Received February 2, 2015; Accepted March 27, 2015

DOI: $10.3892 /$ ijo.2015.2962

\begin{abstract}
B7-H3 (CD276), known as a member of B7 immunoregulatory family, is a type I transmembrane glycoprotein aberrantly expressed in numerous types of cancer and associated with poor prognosis. However, the role of B7-H3 in oncogenesis and chemosensitivity of mantle cell lymphoma (MCL) remains unknown. We determined the effects of downregulating $\mathrm{B} 7-\mathrm{H} 3$ expression on tumor progression and the sensitivity of chemotherapeutic drug in mantle cell lymphoma. B7-H3 knockdown was performed using lentivirus transduction in the Maver and Z138 mantle cell lymphoma cell lines, respectively. The effects of B7-H3 on cell proliferation, cycle, migration and invasion were investigated by $\mathrm{CCK}-8$ assay, methyl cellulose colony forming assay, PI staining, and Transwell assays in vitro. By establishing Maver and Z138 xenograft models, the effects of B7-H3 on tumorigenicity were observed, and Ki-67 and PCNA was detected by immunohistochemistry. The downregulation of B7-H3 significantly decreased tumor proliferation in MCL in vitro and in vivo. In the B7-H3 knockdown groups of Maver and Z138 xenograft models, the mean inhibition rate of tumor growth was 59.1 and $65.0 \%(\mathrm{p}=0.010$ and 0.003$)$, and the expression of both Ki-67 and PCNA were significantly lower, respectively. After B7-H3 silencing, the cell cycles of Maver and Z138 were both arrested at G0/G1 phase, and the cell migration rates and invasion capacity were decreased as well. Moreover, the impacts of B7-H3 RNAi on the antitumor effect of chemotherapy drugs were determined with CCK-8 and Annexin V-FITC/PI assays in vitro and with xenograft models in vivo. The silencing of B7-H3 increased the sensitivity of Maver and Z138 cells to rituximab and bendamustine and enhanced the drug-induced apoptosis, respectively. Our study demonstrates for the first
\end{abstract}

Correspondence to: Dr Xiaoyan Ke, Department of Hematology and Lymphoma Research Center, Peking University Third Hospital, 49 North Garden Road, Haidian District, Beijing 100191, P.R. China E-mail: xykbysy@163.com

Abbreviations: MCL, mantle cell lymphoma; NHL, non-Hodgkin lymphoma; FBS, fetal bovine serum

Key words: B7-H3, mantle cell lymphoma, cancer gene therapy, chemosensitivity time that $\mathrm{B} 7-\mathrm{H} 3$ promotes mantle cell lymphoma progression and B7-H3 knockdown significantly enhances the chemosensitivity. This may provide a new therapeutic approach to mantle cell lymphoma.

\section{Introduction}

Mantle cell lymphoma (MCL), a heterogeneous subtype of B-cell non-Hodgkin lymphoma (NHL), accounts for $\sim 7 \%$ of NHL cases in the USA and Europe and has one of the worst outcomes of all the lymphomas $(1,2)$. It is characterized by the $\mathrm{t}(11 ; 14)$ (q13;q32) translocation, which results in overexpression of cyclin D1 and deregulation of the cell cycle (2). At initial diagnosis, most patients with the median age $\sim 68-70$ years have advanced stage disease, and the median overall survival is 3-5 years (3). Although several novel agents have proven to be effective, MCL remains a largely incurable disease and the following relapse is still challenging. Therefore, understanding the molecular mechanisms of MCL pathogenesis and drug resistance will aid in the development of highly active targeted therapies for the disease.

B7-H3, a new member of B7 immunoregulatory family with immunoglobulin-like structure (4), is induced in activated dendritic cells, monocytes and T cells (5). Aberrant expression of B7-H3 has been reported and associated with poor prognosis in patients with neuroblastoma (6), lung cancer (7), pancreatic cancer (8), colorectal cancer (9), hepatocellular carcinoma (10) and breast cancer (11). In hematologic malignancy, the overexpression of B7-H3 also has been described, including acute leukemia (12), multiple myeloma (13) and several types of lymphoma (14).

The physiological and pathological role of B7-H3 remains contentious, with stimulatory $(4,15,16)$ and inhibitory $(17-19)$ immunoregulatory functions in cellular and antitumor immune response described in early studies. Currently, the non-immunological functions of B7-H3 in cancer progression and chemoresistance have received increasing attention. Tekle et al demonstrated that the $\mathrm{B} 7-\mathrm{H} 3$ silencing reduced metastatic capacity of MDA-MB-435 melanoma cells and significantly increased the survival of nude mice (20). Other studies also reported that B7-H3 was important in regulating the adhesive, migratory, and invasive capacity in breast cancer (21), glioblastoma (22), pancreatic cancer (23), prostate cancer (24) and osteosarcoma (25). Liu et al discovered that silencing 
of B7-H3 sensitized the breast cancer cell lines to paclitaxel by abrogating Jak2/Stat3 phosphorylation (26). In pancreatic carcinoma cells, B7-H3 was demonstrated to induce gemcitabine resistance as well (27). The above research indicated that B7-H3 may be a potential therapeutic target.

However, little is known about the direct impact of B7-H3 on tumor progression and B7-H3 RNAi-based targeting therapy in MCL. In this study, we investigated the role of B7-H3 in mantle cell lymphoma Maver and Z138 cell proliferation, the cell cycle, migration, invasion and in the chemosensitivity in vitro and in vivo.

\section{Materials and methods}

Cell line and cell culture. Human mantle cell lymphoma Maver and Z138 cell lines were obtained from the American Type Culture Collection (ATCC, Rockville, MD, USA). The cells were, respectively cultured in Iscove's modified Dulbecco's medium (IMDM) and RPMI-1640 (Gibco Invitrogen, Grand Island, NY, USA) medium containing $2 \mathrm{mM}$ L-glutamine, $100 \mathrm{U} / \mathrm{ml}$ penicillin, $100 \mu \mathrm{g} / \mathrm{ml}$ streptomycin and $10 \%$ heatinactivated fetal bovine serum (FBS) (Thermo Scientific HyClone, South Logan, UT, USA), at $37^{\circ} \mathrm{C}$ in a $5 \% \mathrm{CO}_{2}$ incubator.

Lentivirus-based RNA interference transfection and generation of stable cell lines. The human B7-H3 (Gene ID: 80381) targeting small hairpin RNA (shRNA) sequence 5'-TCGTG TGCTGGAGAAAGATCAAACAGAGC-3' and a negative non-targeted control sequence 5'-GCACTACCAGAGCTAA CTCAGATAGTACT-3' were used to generate recombinant lentiviral particles (20). These recombinant lentivirus were prepared and titered to $5 \times 10^{9} \mathrm{TU} / \mathrm{ml}$ (transfection unit), and the multiplicity of infection (MOI) was 10. Antibiotic-resistant clones were isolated and maintained in medium containing $200 \mu \mathrm{g} / \mathrm{ml}$ puromycin (Sigma-Aldrich, St. Louis, MO, USA). The B7-H3 knockdown was confirmed by RT-PCR, western blotting and fluorescence activating cell sorter (FACS). The infected cells comprised the B7-H3 shRNA (KD) and negative non-targeted control (NC) groups, and the non-infected cells were the control (CON) groups. These three groups of each cell line were used for the following experiments.

Gene expression of B7-H3, RT-PCR, western blotting and flow cytometry. Total RNA was extracted and reverse transcribed for cDNA. The primers used for PCR were as follows: 5'-CTC TGCCTTCTCACCTCTTTG-3' (forward) and 5'-CCTTGAG GGAGGAACTTTATC-3' (reverse) for B7-H3 (134 bp) (23); 5'-TTGACGGTAAGGACGGACTC-3' (forward) and 5'-ACTT GCAGTACTCCCCATCG-3' (reverse) for matrix metalloproteinase-2 (MMP-2, 153 bp); 5'-TTGACAGCGACAAGAAG TGG-3' (forward) and 5'-CCCTCAGTGAAGCGGTACAT-3' (reverse) for matrix metalloproteinase-9 (MMP-9, 148 bp) (28); and 5'-TGACGTGGACATCCGCAAAG-3' (forward) and 5'-CTGGAAGGTGGACAGCGAGG-3' (reverse) for $\beta$-actin (205 bp). The PCR conditions were $94^{\circ} \mathrm{C}$ for $2 \mathrm{~min}$, then 28-36 cycles (B7-H3/MMP-2/MMP-9: 36 cycles; $\beta$-actin: 28 cycles) at $94^{\circ} \mathrm{C}$ for $30 \mathrm{sec}, 56-59^{\circ} \mathrm{C}\left(\mathrm{B} 7-\mathrm{H} 3: 56^{\circ} \mathrm{C}\right.$; MMP-2/ MMP-9/ $\beta$-actin: $59^{\circ} \mathrm{C}$ ) for $30 \mathrm{sec}, 72^{\circ} \mathrm{C}$ for $30 \mathrm{sec}$, and finally $72^{\circ} \mathrm{C}$ for $2 \mathrm{~min}$.
The cells were lysed on ice, and the concentration of protein was determined using the BCA method. A total of $30 \mu \mathrm{g}$ proteins were transferred onto nitrocellulose filter (NC) membranes after $10 \%$ SDS-PAGE. The membranes were blocked and incubated with primary antibodies, including rabbit anti-B7-H3 (1:500 dilution, $110 \mathrm{kDa}$ ) (clone EPNCIR122; Epitomics, Burlingame, CA, USA) or mouse anti- $\beta$-actin (1:1,000 dilution, $43 \mathrm{kDa}$ ) (clone C-2; Santa Cruz, CA, USA) monoclonal antibodies overnight at $4^{\circ} \mathrm{C}$. After incubation with IRDye $800 \mathrm{CW}$ conjugated goat (polyclonal) anti-rabbit/antimouse IgG secondary antibody (1:10,000 dilution) (LI-COR, $\mathrm{NE}$, USA) for $1 \mathrm{~h}$, the fluorescent bands was visualized with an Odyssey infrared imaging system (LI-COR), and the gray values were analyzed using Odyssey V3.0 software.

Single cell suspensions were stained with antibodies on ice for $30 \mathrm{~min}$. After three washes in PBS, the cells were analyzed using a flow cytometry system (FACSCalibur; BD Biosciences, San Jose, CA, USA). The monoclonal antibodies used to measure the expression of the cell surface markers by flow cytometry included B7-H3 (CD276)-APC (clone 7-517) from eBioscience (San Diego, CA, USA) and CD3-APC, CD19-APC, CD117-APC, CD20-FITC, CD10-PE, CD5-PE, CD38-FITC, CD56-PE, CD138-APC, CD34-PE, CD45-PerCP, and appropriate isotype controls from BD Biosciences.

CCK-8 assay. The Cell Counting Kit-8 (CCK-8; Dojindo Molecular Technologies, Tokyo, Japan) was used to study the effects of B7-H3 shRNA on cell proliferation. Resuspended cells were plated at $5 \times 10^{4}$ cells/well in a 96 -well plate for $24-$, 48 - or 72-h inoculation. A volume of $10 \mu \mathrm{l} /$ well of CCK-8 solution was added into the plate. After incubation at $37^{\circ} \mathrm{C}$ for $5 \mathrm{~h}$, the absorbance was measured at $450 \mathrm{~nm}$ using a microplate reader. The assay was performed in sextuplicate for each group.

Colony forming assay. A $5 \times 10^{3}$ single-cell suspension was resuspended in $1 \mathrm{ml}$ medium with $20 \%$ FBS and $0.9 \%$ methyl cellulose (Sigma, St. Louis, MO, USA). The samples were plated in 24-well plates and incubated for 14 days. A colony with $>50$ cells was counted as one positive colony. The colony-forming ability $(\mathrm{CFA})=($ colonies counts in experiment group/ control group) x 100\%. Each experiment was repeated three times.

Subcutaneous xenograft model and tumorigenicity assay. Female BALB/c nude mice, 5-6 weeks of age, 16-18 g of weight (Experimental Animal Center, Peking University Health Science Center, Beijing, China), were bred under specified pathogen-free (SPF) conditions. All of the care, experimental procedures and handling of animals were performed with approval of the Institutional Authority for Laboratory Animal Care of Peking University. Mice were pretreated by intraperitoneal (i.p.) injection, with $100 \mathrm{mg} / \mathrm{kg}$ cyclophosphamide (Jiangsu Hengrui Medicine Co. Ltd., China) once daily for two consecutive days. The next day, $2 \times 10^{7}$ cells (the Maver and Z138 cells in CON, NC or KD group respectively, 6 mice per group) in $100 \mu \mathrm{l}$ normal saline (NS) were injected subcutaneously (s.c.) into right axilla region of the nude mice.

The xenografted tumor volume $(\mathrm{V})$ was measured every other day and calculated as: $\mathrm{V}\left(\mathrm{mm}^{3}\right)=$ length $\mathrm{x}$ width ${ }^{2} \mathrm{x} 0.5$. 
The inhibition rate of tumor growth was calculated using the formula: (1 - average tumor weight of treated group/average tumor weight of control group) x $100 \%$.

Immunohistochemical analysis. At the end of observation (20 days post-inoculation), the xenograft tumors of Maver and Z138 mice were excised and fixed in $10 \%$ neutrally buffered formalin for $24 \mathrm{~h}$. After embedded in paraffin, deparaffinized and rehydrated, the histologic sections were subjected to heat-induced epitope retrieval using microwave in $1 \mathrm{mmol} / \mathrm{l}$ EDTA buffer $(\mathrm{pH} 8.0)$ and quenched for endogenous peroxidase activity with $3 \%$ hydrogen peroxide. Then the sections were stained with an rabbit polyclonal antibody to the cell proliferation-associated antigen Ki-67 (1:500 dilution) or a mouse monoclonal antibody to proliferating cell nuclear antigen (PCNA) (1:300 dilution) (Dako Corp., Copenhagen, Denmark), respectively, followed by incubation with the secondary antibody (Dako Corp.) according to the avidin-biotin-peroxidase method. Phosphate-buffered saline (PBS) were used as negative controls. After incubation with 3,3'-diaminobenzidine (DAB) and counterstained with hematoxylin, the sections were analyzed in 5 randomly selected microscopic fields $(400 \mathrm{x})$. The $\mathrm{Ki}-67$ labeling index or the positive expression rate of PCNA $=$ (positively stained cells counts / the total number of nucleated cells) x $100 \%$.

Cell cycle analysis. The Maver and Z138 cells in each group were collected, washed with PBS and fixed in $70 \%$ ethanol overnight at $-20^{\circ} \mathrm{C}$. The cellular DNA was stained with propidium iodide (PI) $(500 \mu \mathrm{g} / \mathrm{ml})$ (Biosea, China) $\left(10 \mu \mathrm{l} / 10^{5}\right.$ cells) for $10 \mathrm{~min}$ at room temperature. The DNA content and cell number were determined by FACS analysis, and the cell cycle profiles were analyzed using the ModFit program (Verify Software House, Inc.). The proliferation index (PI) was calculated using the following equation: $\mathrm{PI}=[(\mathrm{S}+\mathrm{G} 2 \mathrm{M}) /(\mathrm{G} 0 / \mathrm{G} 1+\mathrm{S}+\mathrm{G} 2 \mathrm{M})] \mathrm{x}$ $100 \%$. Each experiment was repeated three times.

Cell migration and invasion assay. For the in vitro migration and invasion assays, $4 \times 10^{5}$ or $2 \times 10^{5}$ cells were resuspended in serum-free medium and placed on the top of an $8-\mu \mathrm{m}$ pore size Transwell chamber (8.0 $\mu \mathrm{m}$ PC, Corning-Costar, Corning, NY, USA) or Matrigel (1:5 dilution) (BD Biosciences, San Jose, CA, USA) invasion chambers. The lower chambers contained medium with $10 \%$ FBS. After 24 h of incubation, the migrating cells in the lower chamber or invading cells on the bottom of each well were stained with 4',6-diamidino-2-phenylindole (DAPI) $(1 \mathrm{mg} / \mathrm{ml}$, Solarbio, China) or $0.1 \%$ crystal violet following by fixation in methyl alcohol for $30 \mathrm{~min}$, respectively. Then, the number of cells in 6 randomly selected microscopic fields (200x) was counted with a BX51 fluorescence microscope (Olympus, Japan) or a DMIL inverted phase microscope (Leica, German). The migration rate $=$ (cells counts in the lower chamber / total number on the top of Transwell chamber) x 100\%. MMP-2 and MMP-9 were detected by RT-PCR to further determine the abilities of tumor cells to penetrate the cell matrix. Each experiment was repeated three times.

Analysis of drug-induced cytotoxicity and apoptosis. Rituximab ( R, 500, 1,000, 1,500, 2,000, 2,500, 3,000, 3,500 and $4,000 \mu \mathrm{g} / \mathrm{ml}$ ) [MabThera, Roche Pharma Ltd., Germany] or bendamustine (Ben, 1, 2, 4, 8, 10, 16, 20 and $40 \mu \mathrm{g} / \mathrm{ml}$ ) (Ribomustin, Ribosepharm $\mathrm{GmbH}$, Germany) was added to three groups of Maver and Z138 cells for 24, 48 or $72 \mathrm{~h}$ respectively, and then the absorbance was detected using the CCK-8 reagent to evaluate the effects of cell proliferation inhibition by the chemotherapy drugs.

A total of $4 \times 10^{5}$ Maver cells in each group were grown in triplicate in 6-well plates with $3,500 \mu \mathrm{g} / \mathrm{ml} \mathrm{R}$ and/or $4 \mu \mathrm{g} / \mathrm{ml}$ Ben for 12 and $24 \mathrm{~h}$, while the same counts of Z138 cells with $2,500 \mu \mathrm{g} / \mathrm{ml} \mathrm{R}$ and/or $4 \mu \mathrm{g} / \mathrm{ml}$ Ben. A volume of $10 \mu \mathrm{l}$ Annexin V-FITC (20 $\mu \mathrm{g} / \mathrm{ml})$ (Biosea, China) was added to the collected cells. After incubation for $15 \mathrm{~min}$ at room temperature, $300 \mu \mathrm{l}$ binding buffer was added. Then, we added $10 \mu \mathrm{l}$ PI $(50 \mu \mathrm{g} / \mathrm{ml})$ (Biosea, China) to the mixtures. The cells were examined by flow cytometry within $1 \mathrm{~h}$ to determine the cell apoptosis rates induced by the chemotherapy drugs. CellQuest software (Becton-Dickinson) was used for data acquisition and analysis.

Caspase- 3 assay. The Maver cells $\left(8 \times 10^{6}\right.$ cells/dish) were treated with $3,500 \mu \mathrm{g} / \mathrm{ml} \mathrm{R}$ and/or $4 \mu \mathrm{g} / \mathrm{ml}$ Ben for 0 and $24 \mathrm{~h}$, while the same counts of Z138 cells were treated with $2,500 \mu \mathrm{g} / \mathrm{ml} \mathrm{R}$ and/or $4 \mu \mathrm{g} / \mathrm{ml}$ Ben. The cells were then collected and lysed on ice for $1 \mathrm{~h}$. The concentration of protein was detected using the BCA method. A total of $150 \mu \mathrm{g}$ protein was detected using the caspase-3 Colorimetric Assay kit (Keygen, China). The activity of caspase- $3=\mathrm{OD}_{405}$ in the experiment group/OD ${ }_{405}$ in the control group.

The effect of B7-H3 RNAi on chemosensitivity in vivo. Mice bearing non-infected Maver and Z138 cell xenografts were allocated randomly into 10 groups respectively (6 mice per group), including: a) an equal volume of $\mathrm{NS}, \mathrm{b}) \mathrm{R}(50 \mathrm{mg} / \mathrm{kg}$ ), c) negative non-targeted control plasmid $(\mathrm{pNC})+\mathrm{R}$, d) short hairpin RNAs targeting B7-H3 plasmid (pKD) $+\mathrm{R}$, e) Ben $(25 \mathrm{mg} / \mathrm{kg}), \mathrm{f}) \mathrm{pNC}+\mathrm{Ben}, \mathrm{g}) \mathrm{pKD}+\mathrm{Ben}, \mathrm{h}) \mathrm{R}+\mathrm{Ben}$, i) $\mathrm{pNC}$ $+\mathrm{R}+\mathrm{Ben}, \mathrm{j}) \mathrm{pKD}+\mathrm{R}+\mathrm{Ben}$. The treatments began at day 8 and day 10 after inoculation, respectively, for Maver and Z138 mice, when tumors reached an average volume of $100 \mathrm{~mm}^{3}$. The chemotherapy drugs and NS were i.p. administered, while the mixture of plasmid DNA $(10 \mu \mathrm{g})$ and Lipofectamine 2000 (30 $\mu \mathrm{l}$; Invitrogen) in $50 \mu \mathrm{l}$ NS were intratumorally injected. All of the treatments were performed every other day, for a total of three times.

Statistical analysis. The data are shown as the mean \pm standard deviation (SD) of triplicate values for each experiment. Statistical comparisons were performed using Student's t-test. A value of $\mathrm{p}<0.05$ was considered statistically significant. The statistical analysis was performed using SPSS 18.0 software (Chicago, IL, USA).

\section{Results}

B7-H3 stably silences MCL cell line generation. B7-H3 knockdown in Maver and Z138 cells was performed using lentivirus transduction to stably express shRNA targeting B7-H3. There was no significant difference of B7-H3 expression between the parental non-infection (CON) cells and the transfection negative non-targeted control cells (NC) in each 

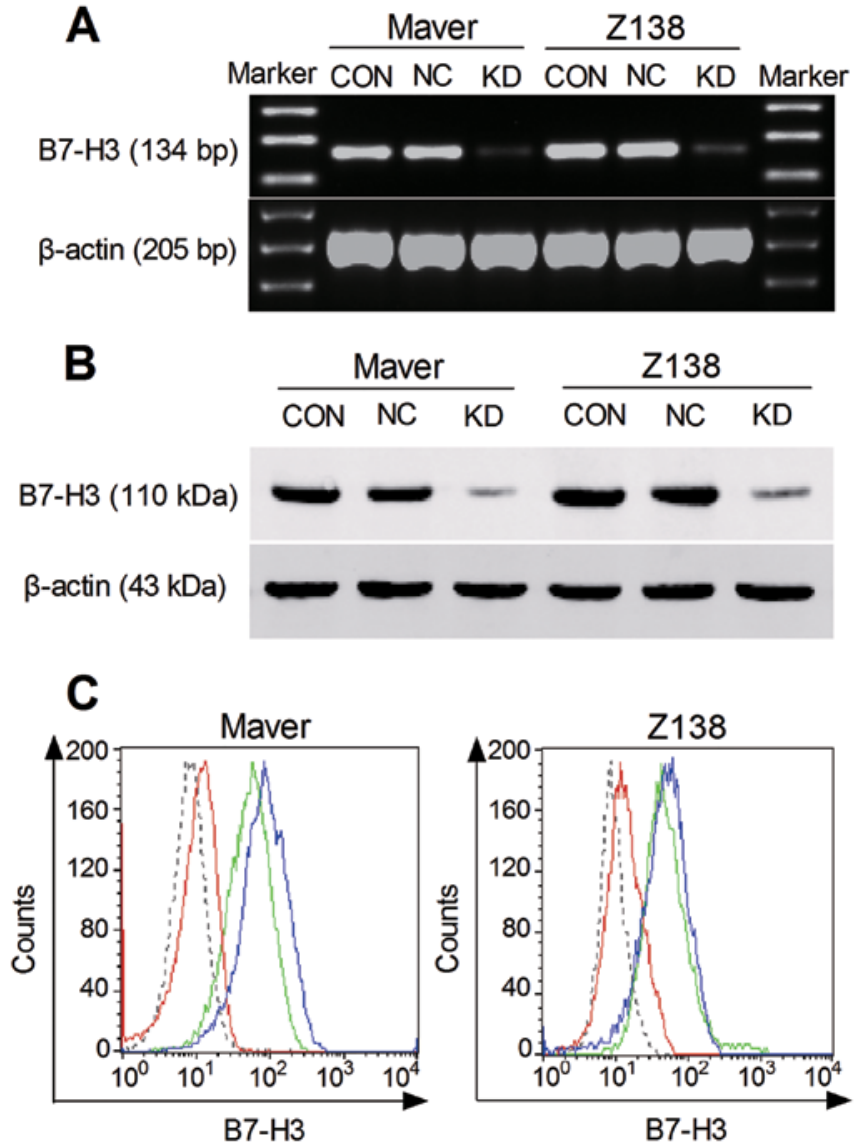

Figure 1. The effect of silencing B7-H3 by shRNA in MCL cells. (A) B7-H3 mRNA knockdown is shown by RT-PCR. (B) B7-H3 nuclear and cytoplasmic protein was knocked down as determined by western blotting. $\beta$-actin was probed as a positive control. (C) B7-H3 membrane protein knockdown was determined by FACS. The blue line represents the CON group, the green line is the $\mathrm{NC}$ group, the red line is the KD group, and gray line is the isotype control. The data are from at least three separate experiments.

cell line by RT-PCR, western blotting and FACS ( $\mathrm{p}>0.05)$. The B7-H3 expression in the shB7-H3/Maver and shB7-H3/Z138 cells (KD groups) was decreased compared to the relative $\mathrm{NC}$ groups $(\mathrm{p}<0.05)$. The inhibition rates of mRNA expression in Maver and Z138 cells were 84.5 and $81.2 \%$, whereas the nuclear and cytoplasmic proteins were reduced by 80.3 and $74.5 \%$, and the membrane proteins were the most significantly inhibited by 86.9 and $82.4 \%$, respectively (Fig. 1).

B7-H3 knockdown inhibits tumor proliferation in vitro and in vivo. To evaluate the effects of $\mathrm{B} 7-\mathrm{H} 3$ knockdown on tumor cell proliferation in vitro, we used CCK-8 and colony formation assays. The stable knock-down of B7-H3 in Maver and Z138 cells significantly reduced cell growth. Compared to the relative NC groups, the growth of shB7-H3/Maver and shB7-H3/ Z138 cells was decreased by 41.7 and $37.5 \%$ after $72 \mathrm{~h}$ of incubation, respectively ( $\mathrm{p}=0.015$ and 0.028 ) (Fig. 2A). The colony formation assay further confirmed that B7-H3 silencing inhibits Maver and Z138 cell proliferation. At day 14 of incubation, the colony-forming ability (CFA) of shB7-H3/Maver and shB7-H3/Z138 cells was significantly decreased by 71.2 and $77.2 \%$, respectively compared with the NC groups (Fig. 2B).

To detect the in vivo effects of B7-H3 knockdown of tumorigenicity, we established xenograft models by subcutane- ously injecting Maver and Z138 cells into right axilla region of BALB/c nude mice. The increases of tumor volumes in B7-H3 silencing Maver and Z138 mice were slowed down comparing to their NC groups injected with non-targeted sequence transfected cells, while no significant differences were observed between their NC groups and the non-infection groups ( $p>0.05$ ) (Fig. 2C). At day 20 after inoculation, the tumors were excised from the mice and weighed, and the inhibition rates of tumor growth with B7-H3 knockdown were 59.1 and $65.0 \%$ in Maver and Z138 xenograft models $(\mathrm{p}=0.010$ and 0.003) (Fig. 2D). Furthermore, we assessed two markers reflecting tumor cell proliferation activity, Ki-67 and PCNA, through immunohistochemical staining. There were apparently fewer positively $\mathrm{Ki}-67$ and PCNA stained cells in the B7-H3 knockdown groups than in the relative NC groups of Maver and $\mathrm{Z} 138$ xenograft models. The Ki-67 labeling indexes of the excised xenografts in B7-H3 knockdown groups were $34.1 \pm 5.2$ and $42.3 \pm 4.1 \%$, respectively, significantly lower than in the relative $\mathrm{NC}$ groups in Maver and Z138 mice $(\mathrm{p}=0.001$ and 0.001). The B7-H3 knockdown also decreased the positive expression rates of PCNA compared with the $\mathrm{NC}$ groups in the two types of MCL xenograft models $(38.9 \pm 3.9$ vs. $76.4 \pm 5.9$ and $39.9 \pm 2.4$ vs. $80.3 \pm 5.5 \%$ ) (Fig. $2 \mathrm{E}$ ).

B7-H3 knockdown arrests MCL cell cycle at the G0/G1 phase. We used flow cytometry comparing the G0/G1, S and G2/M phases to determine whether B7-H3 expression affects cell cycle progression. Fig. 3A and B, respectively, show that the Maver and Z138 cell cycle progression was inhibited after B7-H3 silencing. The proliferation index (PI) was decreased by $18.46 \%$ in the KD group comparing to the $\mathrm{NC}$ group of Maver cells ( $\mathrm{p}=0.002)$; while it was reduced by $13.49 \%$ in B7-H3 knockdown Z138 cells ( $\mathrm{p}=0.034)$. This suggests that the knockdown of B7-H3 arrests MCL cell cycle at the G0/G1 phase to inhibit cell proliferation.

B7-H3 knockdown inhibits MCL cell migration and invasion. We used Transwell migration and invasion assays to compare the cell migration rate and invasive capacity in each group to determine whether $\mathrm{B} 7-\mathrm{H} 3$ acts as a tumor migration and invasion regulator. Fig. 4A shows that the migration rates of the shB7-H3/Maver and shB7-H3/Z138 cells to the lower chamber were significantly reduced after $24-\mathrm{h}$ incubation compared with the NC groups, with a 6.9 vs. $34.4 \%$ and a 7.4 vs. $63.8 \%$ reduction, respectively. In addition, the invasive capacity of shB7-H3/Maver and shB7-H3/Z138 cells was reduced by 85.5 and $80.1 \%$ compared to the NC groups (Fig. 4B). Both the cell migratory and invasive potential in the $\mathrm{CON}$ and NC groups of Maver and Z138 cells were similar ( $p>0.05)$. Furthermore, we measured the invasion-related proteins by RT-PCR, and found that MMP-2 and MMP-9 were lower in shB7-H3/Maver and shB7-H3/Z138 cells than in the NC groups (Fig. 4C). These results indicate that silencing B7-H3 can impede cell migration and inhibit cell invasion via downregulating the expression of MMP-2 and MMP-9.

B7-H3 knockdown enhances drug-induced cytotoxicity and apoptosis in vitro. To determine whether B7-H3 knockdown affects drug-induced cytotoxicity and apoptosis, we selected $\mathrm{R}$ and Ben, which is increasingly being used for the frontline 
A

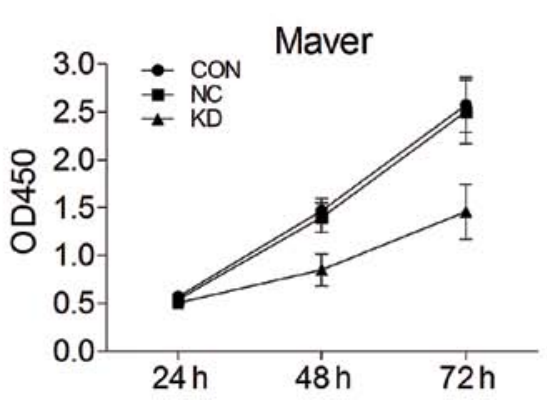

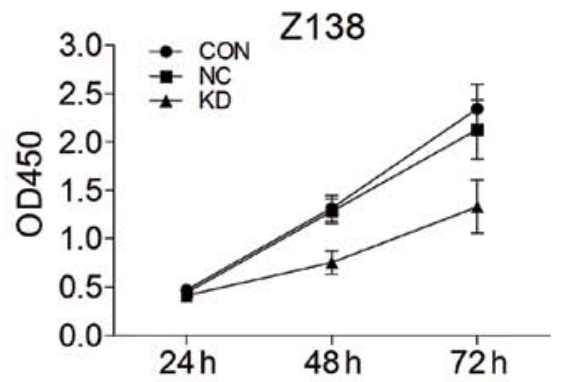

B

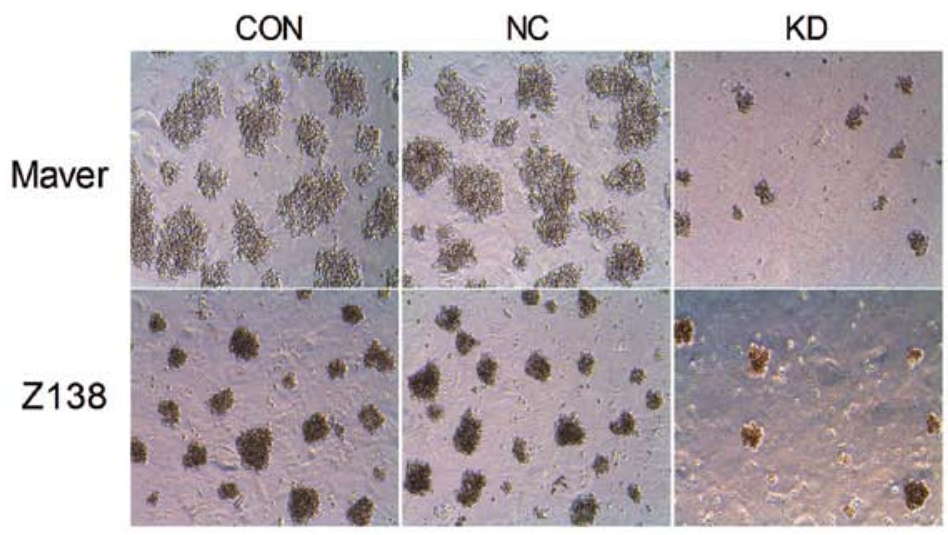

C

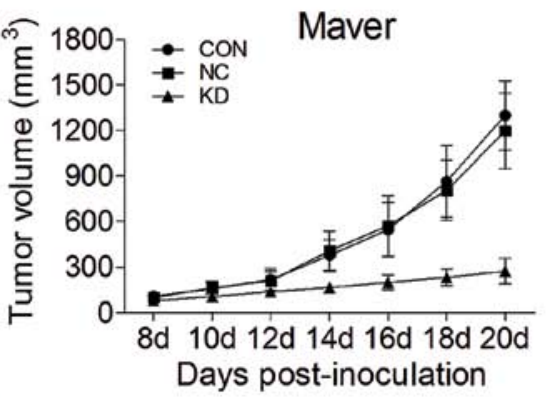

D
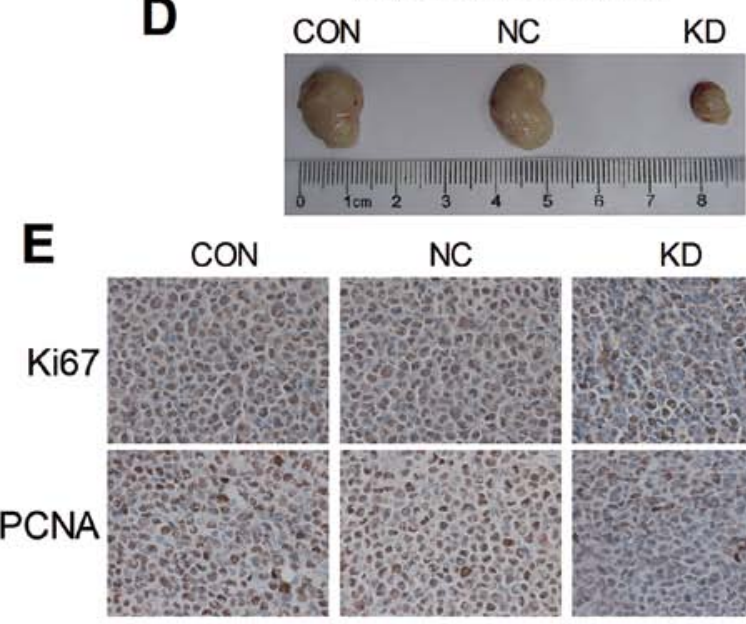

$\mathrm{NC}$

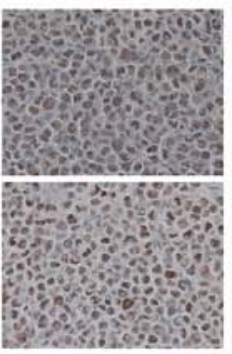

KD
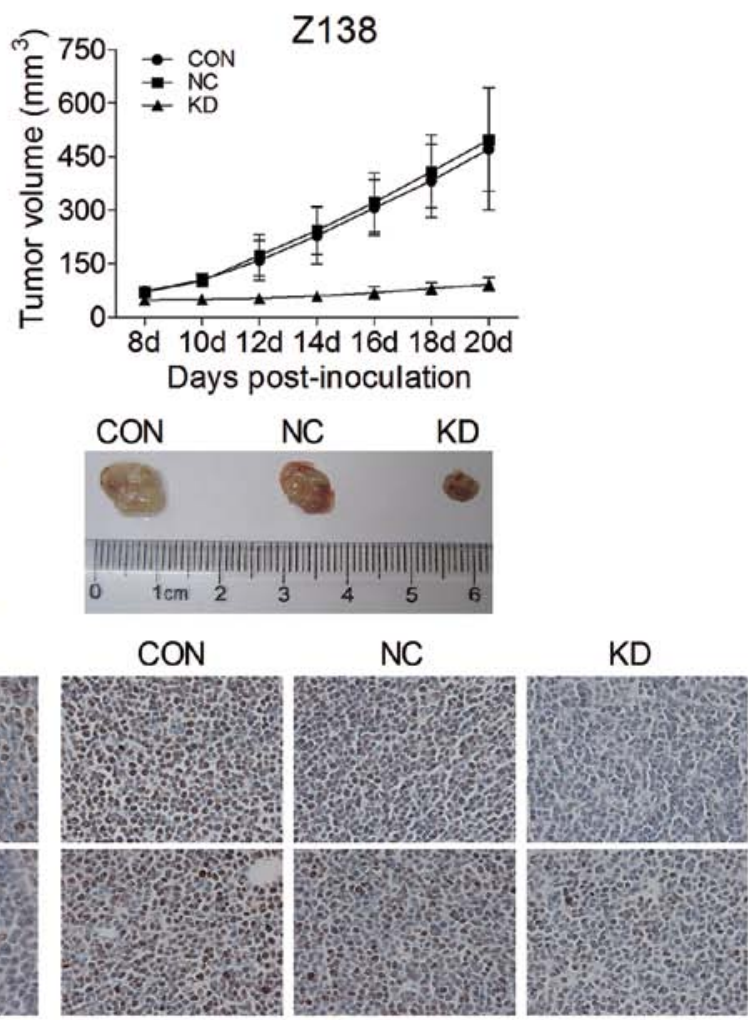

Figure 2. B7-H3 knockdown inhibits tumor proliferation in vitro and in vivo. (A) B7-H3 silencing inhibited the cell growth analyzed by CCK-8 assay. (B) B7-H3 knockdown inhibited the colony formation detected by methyl cellulose colony forming assay (x100). The data are from at least three separate experiments. (C) Silencing of B7-H3 significantly inhibited tumor growth in vivo compared with the negative non-targeted controls (NC). (D) Excised xenograft tumors on day 20. (E) Immunohistochemical staining of Ki-67 and PCNA for proliferative cells in B7-H3 knockdown xenograft was declined comparing to the NC group on day $20(\mathrm{x} 400)$.

treatment of mantle cell lymphoma (29). Following treatment with various concentrations of $\mathrm{R}$ or Ben for 24,48 or $72 \mathrm{~h}$, a dose-dependent and time-dependent inhibition of cell growth was observed in each group of Maver and Z138 cells using the CCK-8 assay (data not shown). Concentrations of 3,500 $\mu \mathrm{g} / \mathrm{ml}$
$\mathrm{R}$ and/or $4 \mu \mathrm{g} / \mathrm{ml}$ Ben were treated in Maver cell groups, while $2,500 \mu \mathrm{g} / \mathrm{ml} \mathrm{R}$ and $/$ or $4 \mu \mathrm{g} / \mathrm{ml}$ Ben were selected for the Z138 cell groups, and then the absorbance was compared (Fig. 5). The cell survival rates in the KD groups of Maver and Z138 cells were significantly decreased compared with their NC 
A

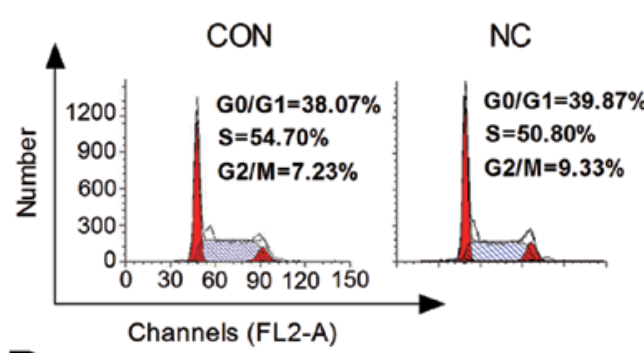

B

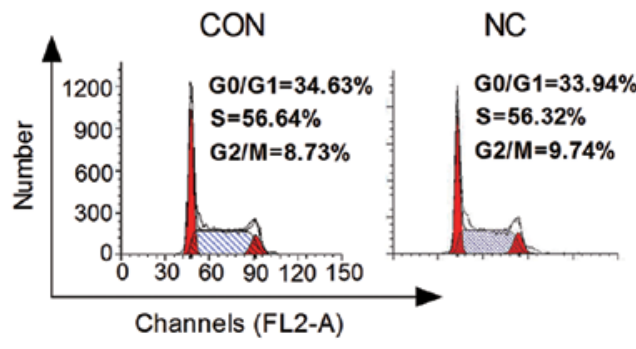

Maver

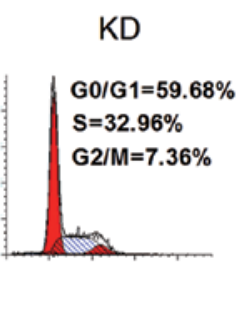

Z138

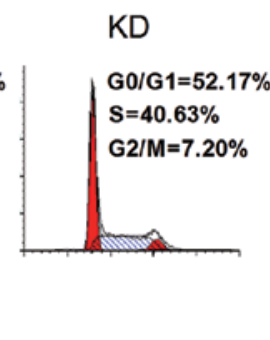

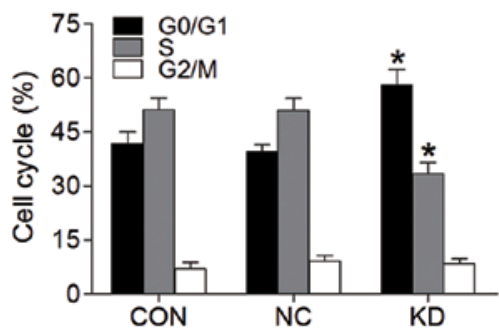

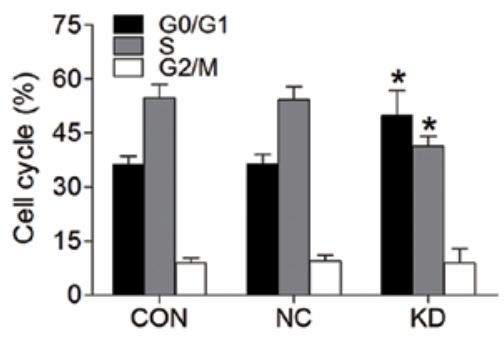

Figure 3. B7-H3 knockdown inhibits cell cycle progression. (A and B) B7-H3 knockdown arrested Maver and Z138 cell cycle at the G0/G1 phase, analyzed by FACS. "Results are statistically significant compared to the NC group, $\mathrm{p}<0.05$. The data are from at least three separate experiments.

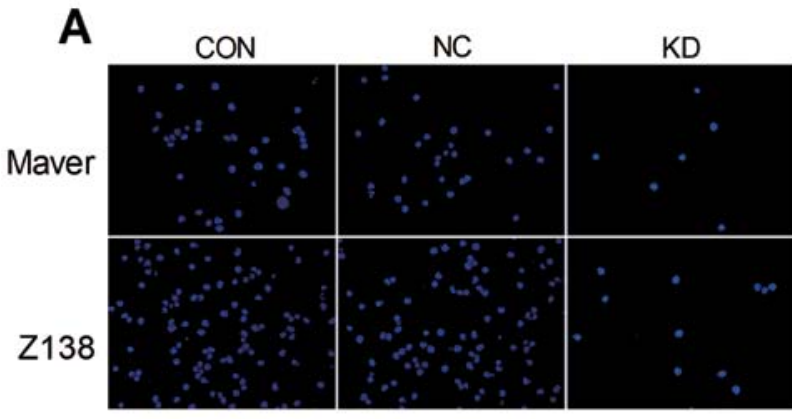

B

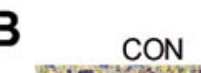

NC

KD

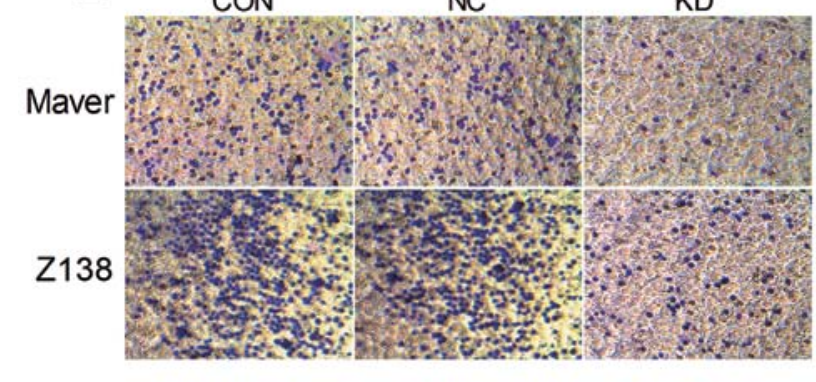

C
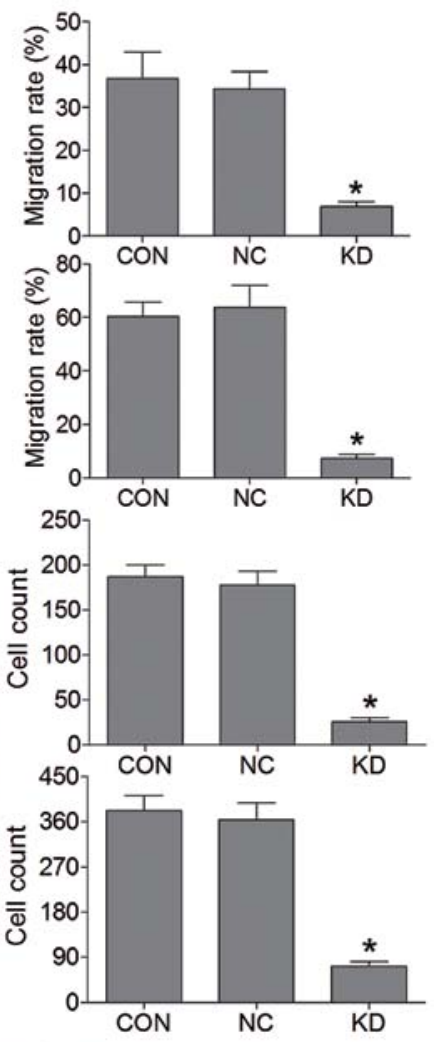

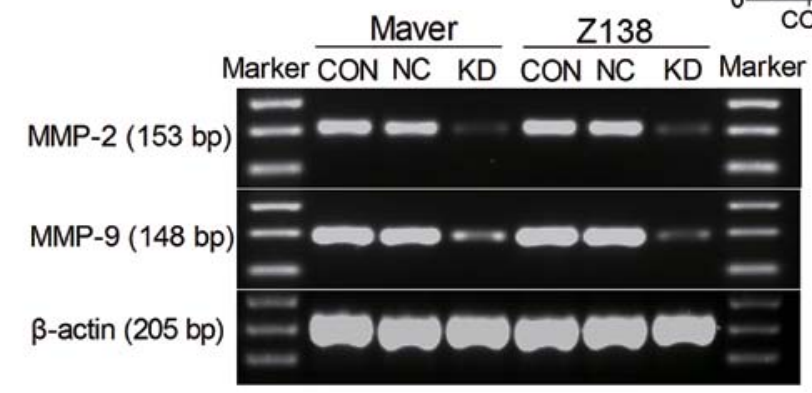

Figure 4. B7-H3 knockdown inhibits tumor migration and invasion. (A) B7-H3 knockdown inhibited tumor migration to the lower chamber (x200). (B) B7-H3 knockdown inhibited tumor invasion capacity (x200). (C) Expression of invasion-related proteins MMP-2 and MMP-9 was lower in B7-H3 silenced cells, monitored by RT-PCR analysis. "Results are statistically significant compared to the NC group, $\mathrm{p}<0.05$. The data are from at least three separate experiments. 


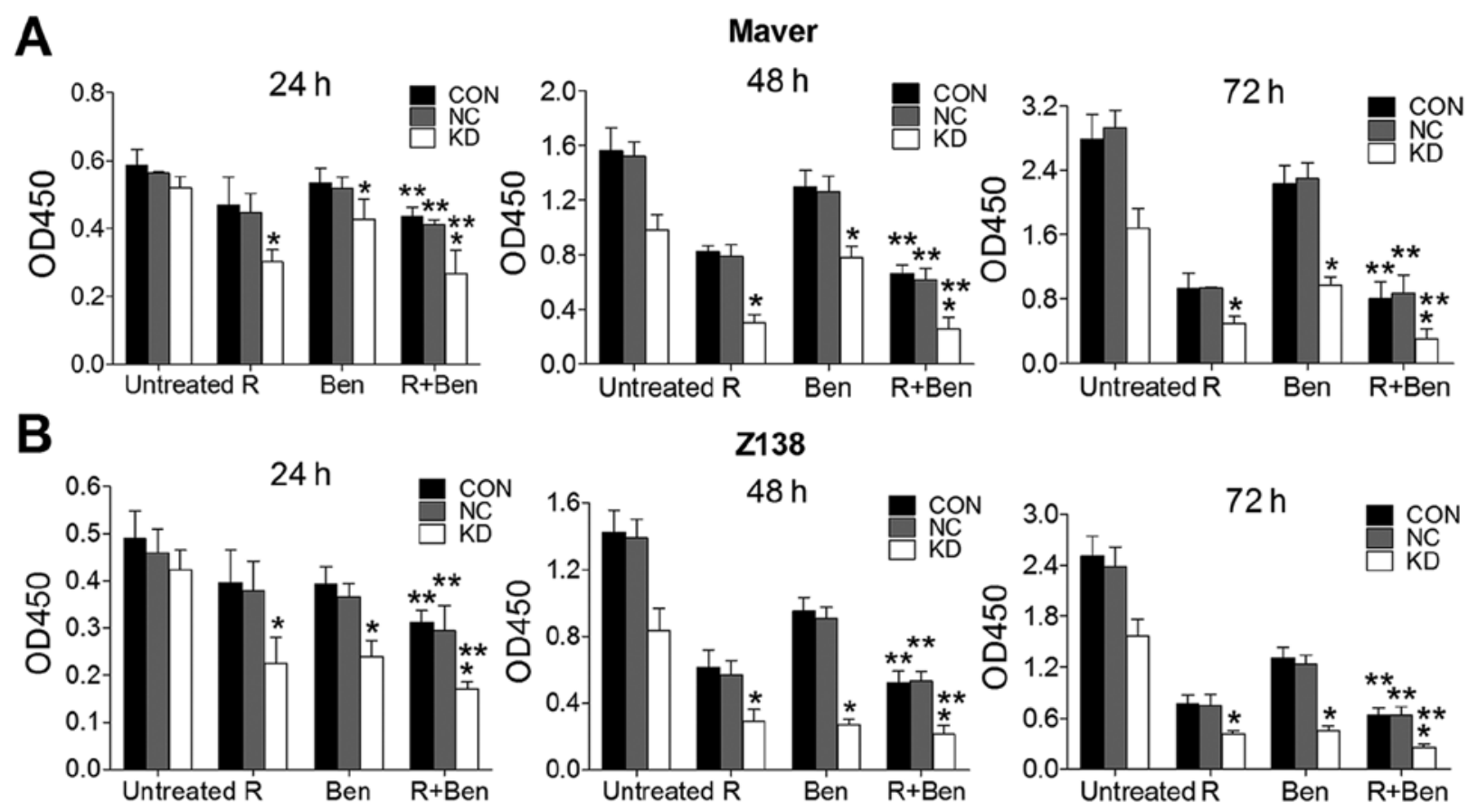

Figure 5. B7-H3 knockdown enhances drug-induced cytotoxicity in vitro. (A and B) B7-H3 knockdown combined with R and/or Ben significantly suppressed tumor cell growth at 24, 48 and $72 \mathrm{~h}$ in Maver and Z138 cells, respectively, analyzed by CCK-8 assay. *Results are statistically significant compared to the $\mathrm{NC}$ group, $\mathrm{p}<0.05 .{ }^{* *}$ Results are statistically significant compared to the single drug Ben group, $\mathrm{p}<0.05$. The data are from at least three separate experiments.

groups $(\mathrm{p}<0.05)$, and these two drug combinations synergistically inhibited MCL cell proliferation.

Exposure to 3,500 $\mu \mathrm{g} / \mathrm{ml} \mathrm{R}$ and/or $4 \mu \mathrm{g} / \mathrm{ml}$ Ben for 12 and $24 \mathrm{~h}$ in Maver cells or $2,500 \mu \mathrm{g} / \mathrm{ml} \mathrm{R}$ and/or $4 \mu \mathrm{g} / \mathrm{ml}$ Ben in Z138 cells suggested that B7-H3 silencing promoted apoptosis in a time-dependent manner. The apoptosis rates of shB7-H3/ Maver cells in the drug combination groups were $63.84 \pm 7.07 \%$ for $12 \mathrm{~h}$ and $82.43 \pm 4.68 \%$ for $24 \mathrm{~h}$, which were the most significantly increased $(\mathrm{p}=0.008$ and 0.001$)$. The same conclusion can be drawn for Z138 cells $(68.06 \pm 7.01 \%$ for $12 \mathrm{~h}$ and $95.99 \pm 3.84 \%$ for $24 \mathrm{~h})(\mathrm{p}=0.006$ and 0.002$)$ (Fig. 6A-D). After exposure to $\mathrm{R}$ and/or Ben for $24 \mathrm{~h}$, we measured the activity of the apoptosis-related protein caspase-3. The results demonstrated that the activity of caspase-3 in the KD group of Maver cells compared to the NC group was significantly increased treated with $\mathrm{R}$, Ben, and $\mathrm{R}+\mathrm{Ben}$ (3.32 \pm 0.37 , 3.36 \pm 0.41 , and $4.57 \pm 0.50$ vs. $2.01 \pm 0.35,2.33 \pm 0.26$, and $2.93 \pm 0.61$, respectively) ( $\mathrm{p}=0.011,0.022$, and 0.023 ) (Fig. 6E). Also, the same conclusion can be drawn for Z138 cells $(3.45 \pm 0.43,3.79 \pm 0.31$, and $4.65 \pm 0.31$ vs. $2.42 \pm 0.34,2.68 \pm 0.52$ and $3.40 \pm 0.35$, respectively) ( $\mathrm{p}=0.032,0.034$, and 0.010 ) (Fig. 6F). These results indicate that silencing $\mathrm{B} 7-\mathrm{H} 3$ increases drug-induced cytotoxicity and promotes drug-mediated apoptosis by increasing the caspase-3 activity in vitro.

B7-H3 knockdown increases chemosensitivity in xenograft model. In order to explore the impact of B7-H3 knockdown on the antitumor activity of chemotherapy drugs in vivo, we constructed tumor-bearing mouse models injecting into noninfected Maver and Z138 cells, respectively. The treatments began on day 8 or day 10 in Maver or Z138 xenograft model, when the average tumor volumes reached $100 \mathrm{~mm}^{3}$. As shown in Fig. 6A and E, the plasmids of B7-H3 shRNA (pKD) combined with $\mathrm{R}$ and/or Ben were more effective in reducing the established Maver and Z138 tumor growth comparing to the groups of non-targeted control plasmid (pNC) combining chemotherapy, while there were no significant differences in the tumor volumes between the pNC combined with chemotherapy groups and the chemotherapy groups alone. At the end of observation, the inhibition rates of tumor growth in $\mathrm{pKD}$ combined with R, Ben, and R+Ben groups in Maver xenograft model were $83.3,80.9$ and $92.3 \%$ respectively, which were higher than in the pNC combined with chemotherapy groups with 62.2, 69.5 and $85.4 \%$ ( $\mathrm{p}=0.019,0.049$ and 0.043) (Fig. 7B and $\mathrm{C}$ ). The same conclusion can be drawn for Z138 xenograft model, and the inhibition rates of tumor growth were 83.7, 84.8 and $92.9 \%$ vs. $66.8,64.7$ and $82.1 \%$ ( $\mathrm{p}=0.030,0.009$ and 0.027) (Fig. 7F and G). Both the Maver and Z138 groups of B7-H3 shRNA combined with two drugs received the best antitumor activity. Besides, all of the mice treated with B7-H3 shRNA exhibited no body weight loss at the end of our experiment (Fig. 7D and H). These results indicate that the B7-H3 silencing can apparently enhance chemosensitivity to mantle cell lymphoma in the xenograft model.

\section{Discussion}

In the present study, we first generated and confirmed the Maver and Z138 mantle cell lymphoma cells with targeting B7-H3 knockdown using lentivirus transduction. B7-H3 expression abundance was decreased at the mRNA and protein level in both MCL cell lines. The membrane proteins were the most significantly inhibited by 86.9 and $82.4 \%$, respectively. Therefore, the B7-H3 knockdown was specific and efficient, and the MCL cell models may be used for subsequent assays. 

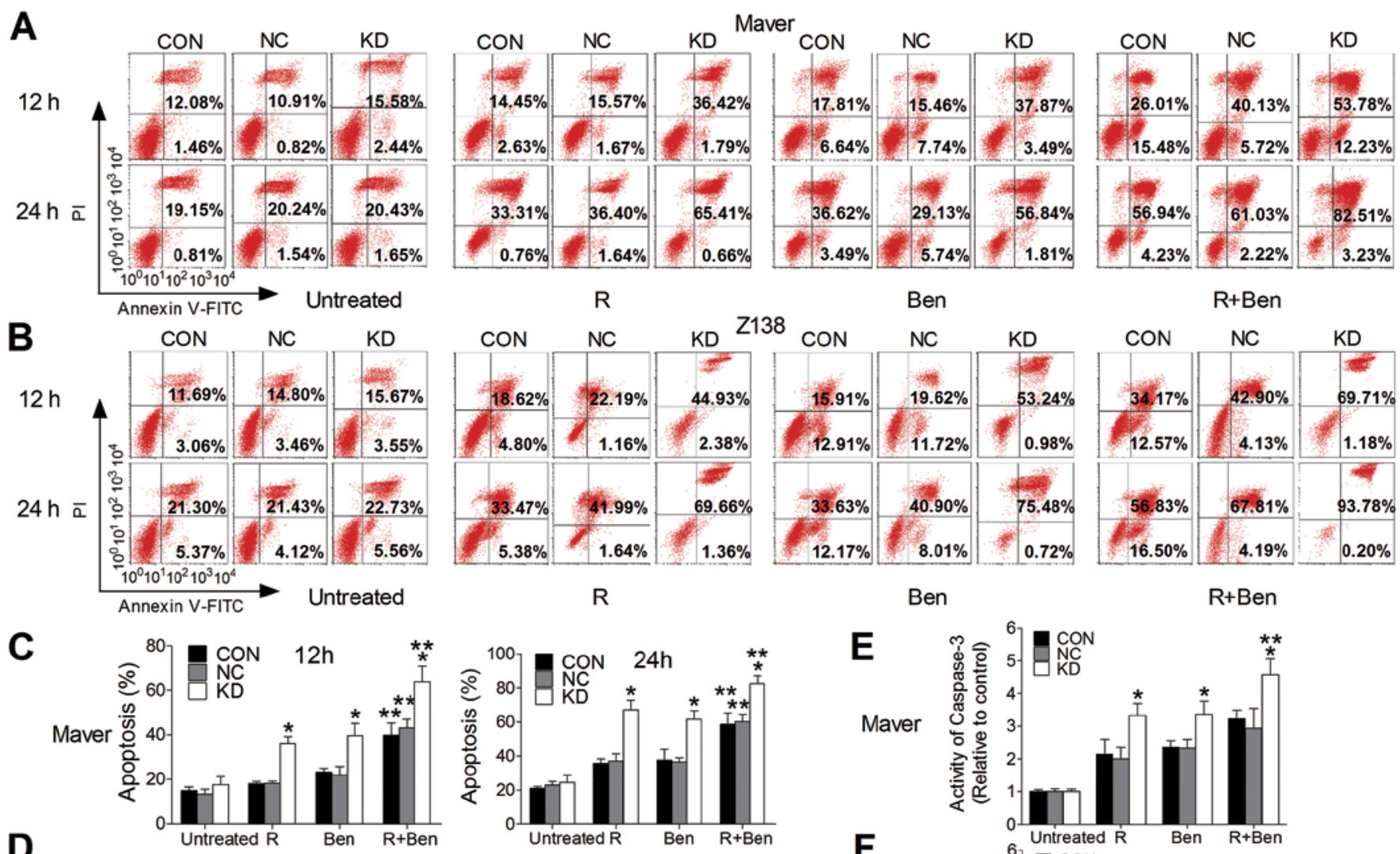

Ben

R+Ben
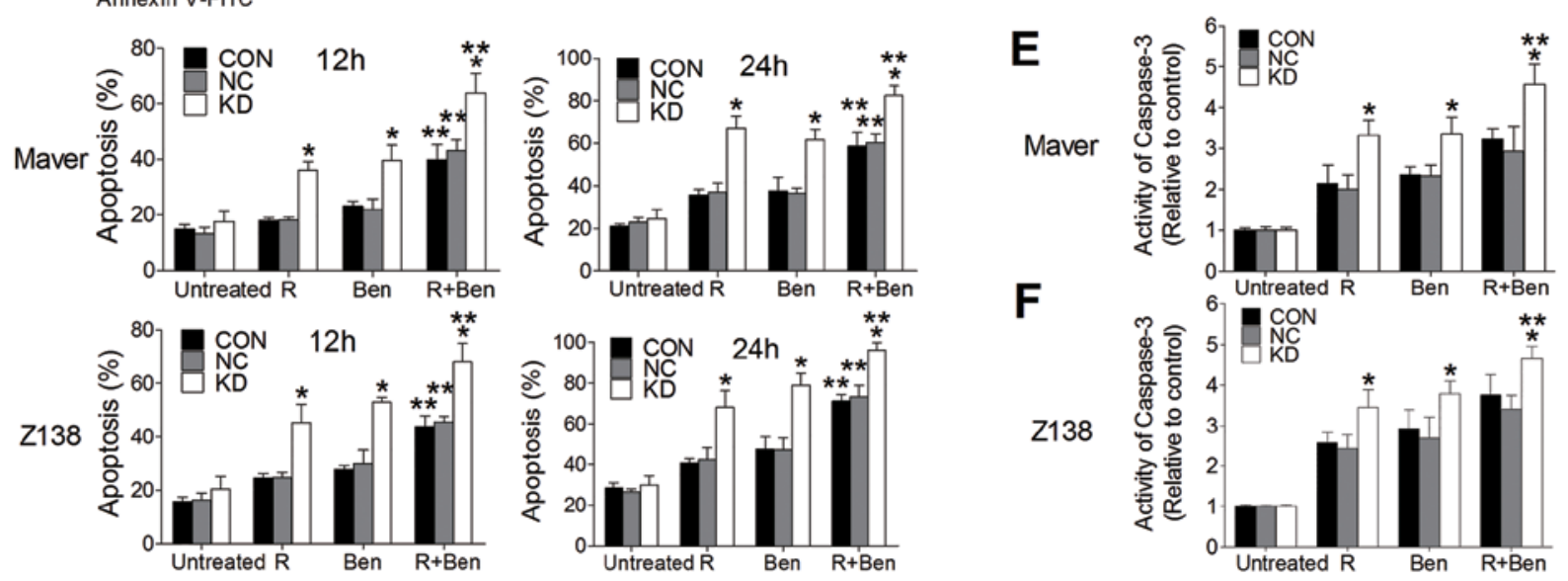

Figure 6. B7-H3 knockdown enhances drug-induced cytotoxicity and apoptosis in vitro. (A-D) In Annexin V-PI staining, B7-H3 silence significantly promoted apoptosis after treatment with R and/or Ben for 12 and $24 \mathrm{~h}$ in Maver and Z138 cells, respectively. (E and F) The activity of caspase-3 was higher in B7-H3 silenced Maver and Z138 cells exposed to R and/or Ben for $12 \mathrm{~h}$ respectively, measured by caspase-3 assay. "Results are statistically significant compared to the NC group, $\mathrm{p}<0.05 .{ }^{* *}$ Results are statistically significant compared to the single drug group, $\mathrm{p}<0.05$. The data are from at least three separate experiments.

Previous studies found that the silencing of B7-H3 did not affect pancreatic (23) and prostate cancer (24) cell proliferation and moderately reduced (20-30\%) the growth of melanoma cells (20) in vitro. Interestingly, we found that artificial silencing of B7-H3 significantly inhibited Maver and Z138 cell growth by 41.7 and $37.5 \%$ in $72 \mathrm{~h}$, compared with the relative NC groups. After 14 days of culture, the colonyforming ability in these two B7-H3 knockdown cell lines were both inhibited by 71.2 and $77.2 \%$, respectively, in contrast to no significant effect on colony formation performing by B7-H3 silence (30). The different effects of B7-H3 may depend on the various tumor types. Then, we established xenograft models to study the in vivo effect of B7-H3 knockdown in tumorigenicity. The growth of established B7-H3 knockdown Maver and Z138 xenografts slowed down compared with their $\mathrm{NC}$ groups by 59.1 and $65.0 \%$ at the end of observation, respectively. The similar growth inhibition of B7-H3-knockdown xenografts in glioma (22), breast cancer (26) and pancreatic cancer (23) has been observed in other reseach. Furthermore, we found that the expressions of Ki-67 and PCNA were significantly decreased in the B7-H3 silenced MCL xenografts. To determine whether B7-H3 knockdown affects the cell cycle, we compared the proliferation index (PI) in shB7-H3/Maver and shB7-H3/Z138 cells with the $\mathrm{NC}$ groups, and found that the $\mathrm{B} 7-\mathrm{H} 3$ silencing arrested the cell cycle at the G0/G1 phase. Clearly, the in vivo results confirmed our in vitro observations, and the above findings indicate that B7-H3 knockdown can inhibit the mantle cell lymphoma proliferation through suppressing cell cycle progression and reducing the expression of $\mathrm{Ki}-67$ and PCNA.

Several studies reported that $\mathrm{B} 7-\mathrm{H} 3$ promoted tumor invasion and metastasis in cutaneous melanoma (30), osteosarcoma (25), and non-small cell lung cancer (31). In this study, we found that both the cell migratory and invasive potential in the B7-H3 knockdown groups of Maver and Z138 cells was reduced compared to the NC groups. Since MMP-2 and MMP-9 are proteolytic enzymes involved in tumor cell migration, invasion, and metastasis (32), we measured the mRNA level of both MMPs by RT-PCR and found that the expressions of MMP-2 and MMP-9 were apparently decreased in shB7-H3/ Maver and shB7-H3/Z138 cells. Tekle et al also showed a 


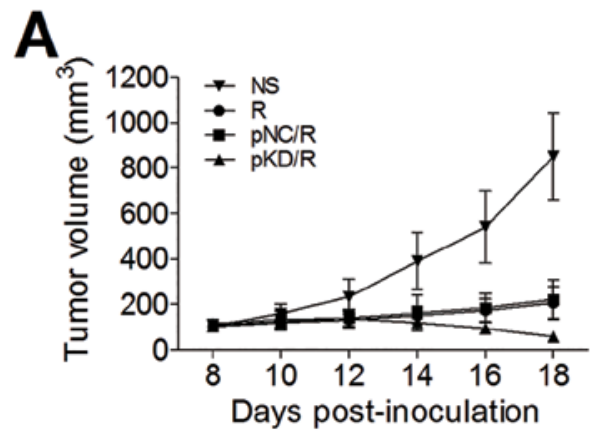

B

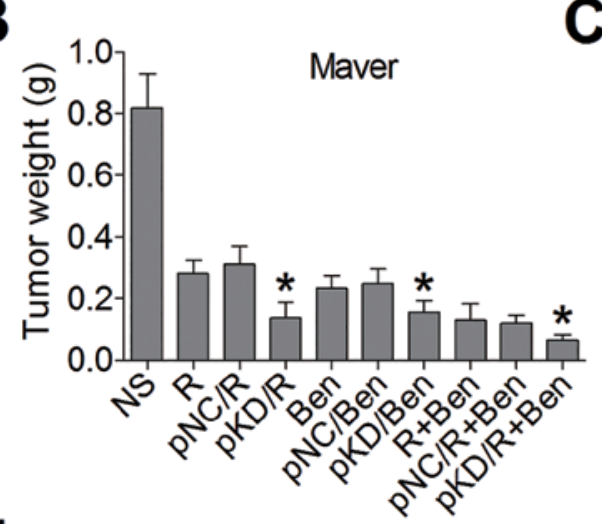

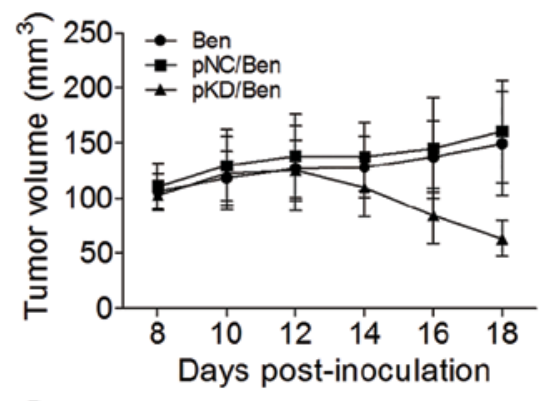

C
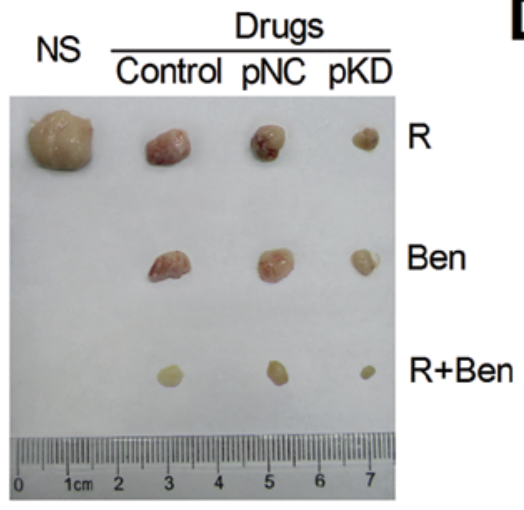

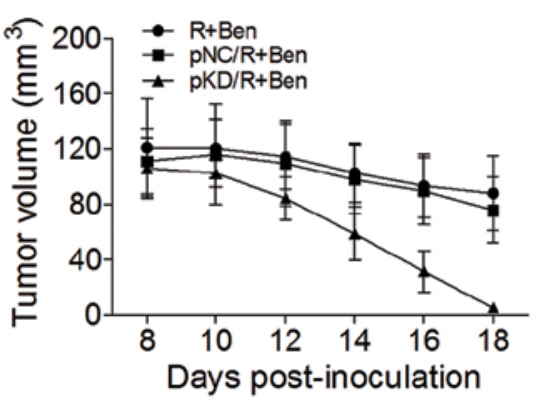

D

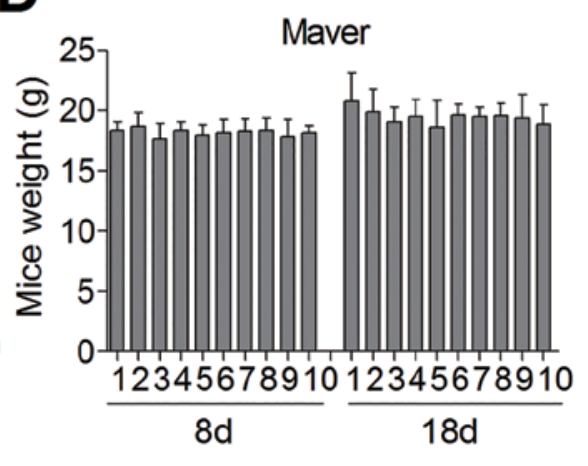

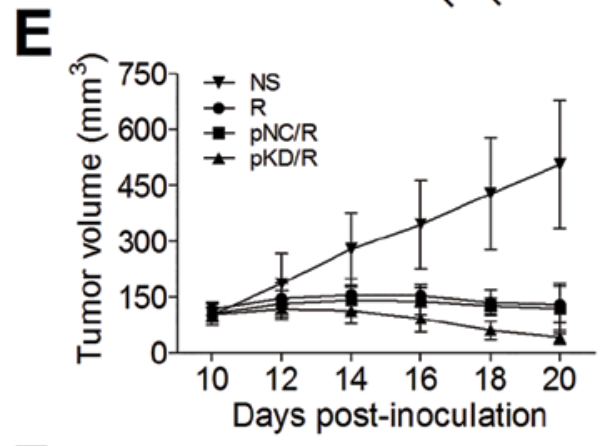

$\mathbf{F}$

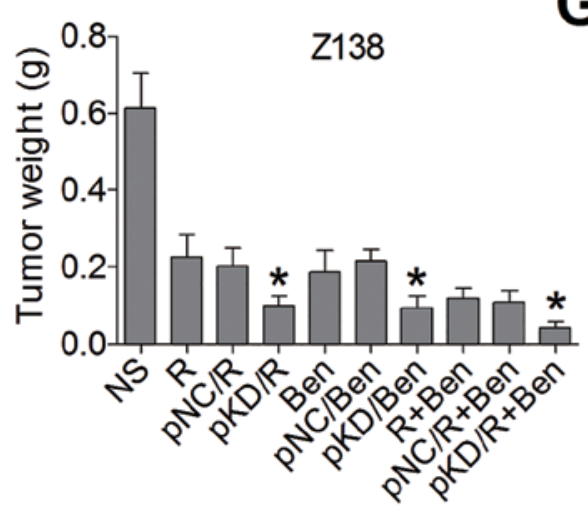

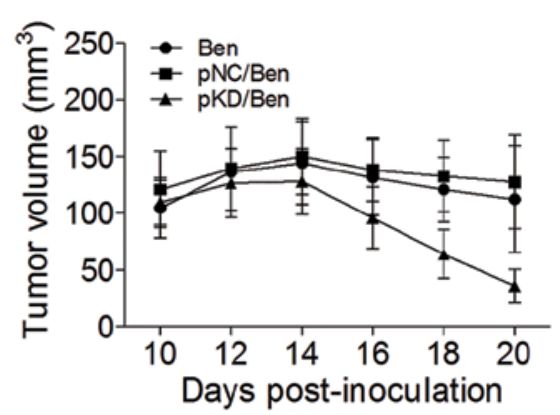

G

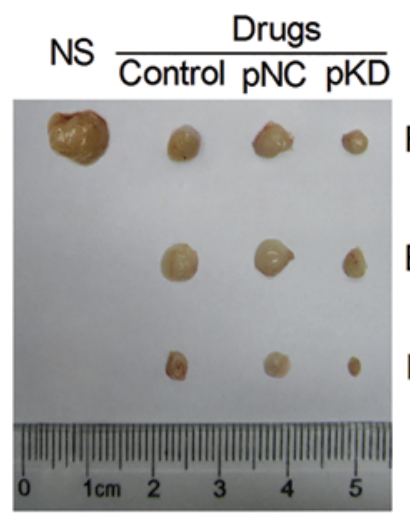

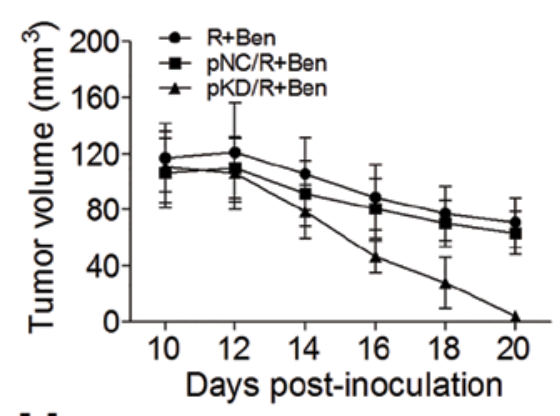

$\mathrm{H}$

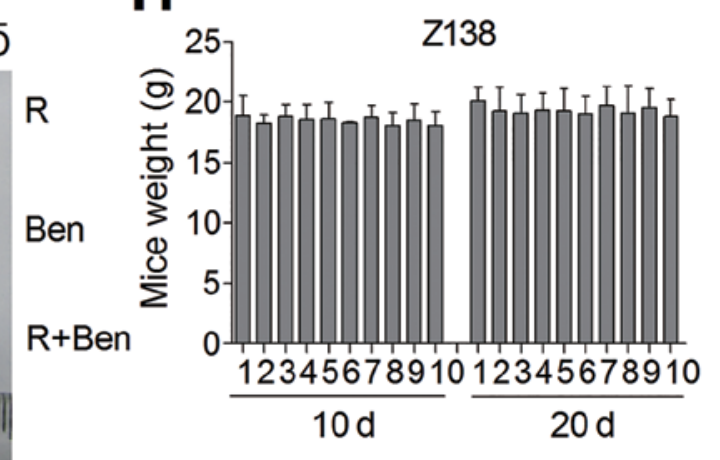

Figure 7. B7-H3 knockdown increases chemosensitivity in vivo. (A and E) B7-H3 shRNA plasmid (pKD) combined with R and/or Ben reduced the tumor growth more effectively than in the non-targeted control plasmid (pNC) combining chemotherapy groups in Maver and Z138 xenograft models, respectively. (B and F) The inhibition rates of tumor growth in the pKD combined with chemotherapy groups were significantly higher than in the pNC combined with chemotherapy groups in Maver and Z138 xenograft models, respectively. (C and G) Xenografts were excised from Maver and Z138 mice at the end of observation. (D and H) The weight of mice in the different groups was measured on the day of treatment and the end of experiment. The mice treated with B7-H3 shRNA exhibited no significant body weight loss compared with the relative pNC control groups. The numbers $1-10$ represent the ten groups of this experiment described in detail in the Materials and methods. "Results are statistically significant compared to the NC group, p<0.05.

similar change of MMP-2 in B7-H3 knockdown melanoma cells (20). It indicates that silencing B7-H3 can impede cell migration and inhibit cell invasion via downregulating the expression of MMP-2 and MMP-9.
In recent years, the prognosis of mantle cell lymphoma has improved likely due to two important factors: the incorporation of high-dose cytarabine in the induction treatment, followed by autologous hematopoietic cell transplantation in first remis- 
sion, and the addition of the anti-CD20 monoclonal antibody rituximab $(\mathrm{R})$ to chemotherapy regimens (33). However, the management of relapsed/refractory disease represents a challenge, and a series of novel agents have entered clinical trials. Among these new strategies, bendamustine (Ben), a bifunctional alkylating agent, in combination with rituximab could be recommended as a first-line therapy for MCL (34). In our study, we first observed the cytotoxic effect and apoptosis induced by $\mathrm{R}$ and/or Ben in Maver and Z138 cells, and the results confirmed that silencing of B7-H3 increases chemosensitivity in both the single drug and two drug combination groups. The synergistic cell apoptotic effects in Maver and Z138 cells induced by $\mathrm{R}$ and Ben were promoted by B7-H3 knockdown in a time-dependent manner. It indicates that B7-H3 knockdown enhances drug-induced cytotoxicity and apoptosis, and a similar conclusion was drawn in B7-H3 silenced breast cancer cells treated with paclitaxel (26). Furthermore, we detected the activity of caspase-3 in Maver and Z138 cells incubated with $\mathrm{R}$ and/or Ben for $24 \mathrm{~h}$, which is the mitochondrial downstream effector caspase in apoptosis signaling cascades. It showed that the blockade of B7-H3 significantly increased the caspase-3 activity induced by $\mathrm{R}$ and/or Ben in Maver and Z138 cells, compared with their NC groups.

With the development of B7-H3 targeted therapeutics, a range of anti-B7-H3 antibodies are under research and some have entered clinical trial for B7-H3-expressing cancers, such as MGA271 (35). In our study, we treated the Maver and Z138 xenograft models with the plasmid of B7-H3 shRNA combined with $\mathrm{R}$ and/or Ben, and found that the inhibition rates of tumor growth were dramatically higher than in the relative non-targeted control plasmid combining chemotherapy groups. At the end of observation, the inhibition rates were even up to 92.3 and $92.9 \%$ in the groups of B7-H3 shRNA combined with two drugs in Maver and Z138 mice, respectively. Our findings in vivo demonstrated that the B7-H3 silence apparently enhanced the chemosensitivity of rituximab and bendamustine to mantle cell lymphoma in the xenograft model. Similar promoting effects of B7-H3 on cancer resistance to drug treatments in breast cancer (26) and pancreatic carcinoma (27) xenograft models have been reported.

In this study, we used RNA interference technology to reduce B7-H3 expression in mantle cell lymphoma cells and xenografts, and found that the knockdown of B7-H3 inhibited tumor proliferation, cell cycle progression, migration and invasion. The silencing of B7-H3 increased drug-induced apoptosis and enhanced therapeutic efficacy. Moreover, further investigations should be performed to explore the exact signaling pathways of B7-H3 contributing to oncogenesis and chemoresistance.

\section{Acknowledgements}

The authors are very grateful to Dr Chen Huang of Key Laboratory of Peking University Third Hospital for assisting with a preparation of this manuscript. This study was supported by a grant from the National Natural Science Foundation of China (81172245).

\section{References}

1. Campo E and Rule S: Mantle cell lymphoma: Evolving management strategies. Blood 125: 48-55, 2015.
2. Chen Y, Wang M and Romaguera J: Current regimens and novel agents for mantle cell lymphoma. Br J Haematol 167: 3-18, 2014.

3. Ghielmini M and Zucca E: How I treat mantle cell lymphoma. Blood 114: 1469-1476, 2009.

4. Chapoval AI, Ni J, Lau JS, Wilcox RA, Flies DB, Liu D, Dong H, Sica GL, Zhu G, Tamada K, et al: B7-H3: A costimulatory molecule for T cell activation and IFN-gamma production. Nat Immunol 2: 269-274, 2001.

5. Steinberger P, Majdic O, Derdak SV, Pfistershammer K, Kirchberger S, Klauser C, Zlabinger G, Pickl WF, Stöckl J and Knapp W: Molecular characterization of human 4Ig-B7-H3, a member of the B7 family with four Ig-like domains. J Immunol 172: 2352-2359, 2004.

6. Xu H, Cheung IY, Guo HF and Cheung NK: MicroRNA miR-29 modulates expression of immunoinhibitory molecule B7-H3: Potential implications for immune based therapy of human solid tumors. Cancer Res 69: 6275-6281, 2009.

7. Chen C, Shen Y, Qu QX, Chen XQ, Zhang XG and Huang JA: Induced expression of B7-H3 on the lung cancer cells and macrophages suppresses T-cell mediating anti-tumor immune response. Exp Cell Res 319: 96-102, 2013.

8. Yamato I, Sho M, Nomi T, Akahori T, Shimada K, Hotta K, Kanehiro H, Konishi N, Yagita H and Nakajima Y: Clinical importance of B7-H3 expression in human pancreatic cancer. $\mathrm{Br}$ J Cancer 101: 1709-1716, 2009.

9. Ingebrigtsen VA, Boye K, Tekle C, Nesland JM, Flatmark K and Fodstad O: B7-H3 expression in colorectal cancer: Nuclear localization strongly predicts poor outcome in colon cancer. Int $\mathrm{J}$ Cancer 131: 2528-2536, 2012.

10. Sun TW, Gao Q, Qiu SJ, Zhou J, Wang XY, Yi Y, Shi JY, Xu YF, Shi YH, Song K, et al: B7-H3 is expressed in human hepatocellular carcinoma and is associated with tumor aggressiveness and postoperative recurrence. Cancer Immunol Immunother 61: 2171-2182, 2012

11. Arigami T, Narita N, Mizuno R, Nguyen L, Ye X, Chung A, Giuliano AE and Hoon DS: B7-h3 ligand expression by primary breast cancer and associated with regional nodal metastasis. Ann Surg 252: 1044-1051, 2010.

12. Hu Y, Lv X, Wu Y, Xu J, Wang L, Chen W, Zhang W, Li J, Zhang S and Qiu H: Expression of costimulatory molecule B7-H3 and its prognostic implications in human acute leukemia. Hematology: Aug 16, 2014 (Epub ahead of print).

13. Zhao D, Lin L, Ge Q, et al: Relation of B7-H3 molecule expression in multiple myeloma with poor prognosis and bone destruction. Zhongguo Shi Yan Xue Ye Xue Za Zhi 21: 637-642, 2013 (In Chinese).

14. Wilcox RA, Ansell SM, Lim MS, Zou W and Chen L: The B7 homologues and their receptors in hematologic malignancies. Eur J Haematol 88: 465-475, 2012.

15. Luo L, Chapoval AI, Flies DB, Zhu G, Hirano F, Wang S, Lau JS, Dong H, Tamada K, Flies AS, et al: B7-H3 enhances tumor immunity in vivo by costimulating rapid clonal expansion of antigen-specific $\mathrm{CD}^{+}$cytolytic $\mathrm{T}$ cells. J Immunol 173: 5445-5450, 2004.

16. Sun X, Vale M,Leung E, Kanwar JR, Gupta R and Krissansen GW: Mouse B7-H3 induces antitumor immunity. Gene Ther 10: 1728-1734, 2003.

17. Brunner A, Hinterholzer S, Riss P, Heinze G and Brustmann H: Immunoexpression of B7-H3 in endometrial cancer: Relation to tumor T-cell infiltration and prognosis. Gynecol Oncol 124: 105-111, 2012.

18. Leitner J, Klauser C, Pickl WF, Stöckl J, Majdic O, Bardet AF, Kreil DP, Dong C, Yamazaki T, Zlabinger G, et al: B7-H3 is a potent inhibitor of human T-cell activation: No evidence for B7-H3 and TREML2 interaction. Eur J Immunol 39: 1754-1764, 2009.

19. Suh WK, Gajewska BU, Okada H, Gronski MA, Bertram EM, Dawicki W, Duncan GS, Bukczynski J, Plyte S, Elia A, et al: The B7 family member B7-H3 preferentially down-regulates Thelper type 1-mediated immune responses. Nat Immunol 4: 899-906, 2003.

20. Tekle C, Nygren MK, Chen YW, Dybsjord I, Nesland JM, Maelandsmo GM and Fodstad O: B7-H3 contributes to the metastatic capacity of melanoma cells by modulation of known metastasis-associated genes. Int J Cancer 130: 2282-2290, 2012.

21. Chen YW, Tekle C and Fodstad O: The immunoregulatory protein human $\mathrm{B} 7 \mathrm{H} 3$ is a tumor-associated antigen that regulates tumor cell migration and invasion. Curr Cancer Drug Targets 8: 404-413, 2008 
22. Lemke D, Pfenning PN, Sahm F, Klein AC, Kempf T, Warnken U, Schnölzer M, Tudoran R, Weller M, Platten M, et al: Costimulatory protein $4 \operatorname{IgB} 7 \mathrm{H} 3$ drives the malignant phenotype of glioblastoma by mediating immune escape and invasiveness. Clin Cancer Res 18: 105-117, 2012.

23. Zhao X, Li DC, Zhu XG, Gan WJ, Li Z, Xiong F, Zhang ZX, Zhang GB, Zhang XG and Zhao H: B7-H3 overexpression in pancreatic cancer promotes tumor progression. Int J Mol Med 31: 283-291, 2013.

24. Yuan H, Wei X, Zhang G, Li C, Zhang X and Hou J: B7-H3 over expression in prostate cancer promotes tumor cell progression. $\mathrm{J}$ Urol 186: 1093-1099, 2011.

25. Wang L, Zhang Q, Chen W, Shan B, Ding Y, Zhang G, Cao N, Liu L and Zhang Y: B7-H3 is overexpressed in patients suffering osteosarcoma and associated with tumor aggressiveness and metastasis. PLoS One 8: e70689, 2013.

26. Liu H, Tekle C, Chen YW, Kristian A, Zhao Y, Zhou M, Liu Z, Ding Y, Wang B, Mælandsmo GM, et al: B7-H3 silencing increases paclitaxel sensitivity by abrogating Jak2/Stat 3 phosphorylation. Mol Cancer Ther 10: 960-971, 2011.

27. Zhao X, Zhang GB, Gan WJ, Xiong F, Li Z, Zhao H, Zhu DM, Zhang B, Zhang XG and Li DC: Silencing of B7-H3 increases gemcitabine sensitivity by promoting apoptosis in pancreatic carcinoma. Oncol Lett 5: 805-812, 2013.

28. Li Y, Wang J, Li C and Ke XY: Contribution of PD-L1 to oncogenesis of lymphoma and its RNAi-based targeting therapy. Leuk Lymphoma 53: 2015-2023, 2012.

29. Rummel MJ, Niederle N, Maschmeyer G, Banat GA, von Grünhagen U, Losem C, Kofahl-Krause D, Heil G, Welslau M, Balser C, et al; Study group indolent Lymphomas (StiL): Bendamustine plus rituximab versus $\mathrm{CHOP}$ plus rituximab as first-line treatment for patients with indolent and mantle-cell lymphomas: An open-label, multicentre, randomised, phase 3 non-inferiority trial. Lancet 381: 1203-1210, 2013.
30. Wang J, Chong KK, Nakamura Y, Nguyen L, Huang SK, Kuo C, Zhang W, Yu H, Morton DL and Hoon DS: B7-H3 associated with tumor progression and epigenetic regulatory activity in cutaneous melanoma. J Invest Dermatol 133: 2050-2058, 2013.

31. Sun Y, Wang Y, Zhao J, Gu M, Giscombe R, Lefvert AK and Wang X: B7-H3 and B7-H4 expression in non-small-cell lung cancer. Lung Cancer 53: 143-151, 2006.

32. Shapiro SD: Matrix metalloproteinase degradation of extracellular matrix: Biological consequences. Curr Opin Cell Biol 10: 602-608, 1998.

33. Mussetti A, Kumar A, Dahi PB, Perales MA and Sauter CS: Lifting the mantle: Unveiling new treatment approaches in relapsed or refractory mantle cell lymphoma. Blood: Nov 1 , 2014 (Epub ahead of print). pii: S0268-960X(14)00083-6. doi: $10.1016 /$ j.blre.2014.10.001.

34. Gil L, Kazmierczak M, Kroll-Balcerzak R and Komarnicki M: Bendamustine-based therapy as first-line treatment for non-Hodgkin lymphoma. Med Oncol 31: 944, 2014.

35. Loo D, Alderson RF, Chen FZ, Huang L, Zhang W, Gorlatov S, Burke S, Ciccarone V, Li H, Yang Y, et al: Development of an Fc-enhanced anti-B7-H3 monoclonal antibody with potent antitumor activity. Clin Cancer Res 18: 3834-3845, 2012. 